\title{
Gender Equity at Work and the Role of the Legal Factors in Albania
}

\author{
Alma Hoti, PhD Cand. \\ European University of Tirana,Albania \\ ab.hoti@yahoo.com
}

\begin{abstract}
Gender equity in general, and gender equity in the context of workand work relations, has been and remains an important issue, which is sensitive and open for debate.Formany scholars the gender equity is the product of social nature factors and those of economic nature. There are also many scholars who associate the degree of gender equity to the role of national or international legal factors, which consist in the role of instruments, actors, and legal institutions. What could explain the upwarddownward dynamics of Gender Equity at Work (GEW) observed in Albania? The extent at which the legal factors have determined the dynamics of GEW in Albania reflects the role and degree of influence of the legal instruments, the legislative, the executive, andjudiciary. What we observed in the case of Albania are two realities: 1) the availability of the necessary tools guaranteeing the GEW and 2) the active role of the legislature, the judiciary and the executive. This paper analyzes the role of instruments, legislative laws, acts of the executive, and the judiciary decisions for the period 2006-2014, and it concludes that although legal factors have a positive impact in guaranteeing GEW, the latter and its upward-downward trends in Albania, more than with the role and influence of legalfactors can and should be explained with the role and influence of social and cultural factors. Gender equity at work in Albania, morethan a matter of instruments, laws of the legislative, acts of the executive, or judicial decisions, it remains at a considerable degree a matter of culture and behavior of the individual on a personallevel, of the social group, or that of the state institutions.
\end{abstract}

Keywords: Gender equity at work , the legislative, the executive, thejudiciary

\section{INTRODUCTION}

Gender equity in general, and gender equity in the context of workand work relations, has been and remains an important issue, which is sensitive and open for debate. Problems in gender relations and respect for gender equity are observed in a number of countries. ${ }^{1}$ However, what distinguishes these countries are the differences in the level as well as tendency over time. World Economic Forum (WEF) measures the level and tendencies of gender equity in two ways: 1) as a combination of fields of economy, education, health, and political representation, and 2) according to a specific field².

Although in the time period 2006-2014 Albania shows an increase of the CGE level ${ }^{3}$, when it is compared with other countries of the world, its performance results to be weaker, which is shown in its ranking. ${ }^{4}$ However, when analyzing performance data of Albania for GEW the dynamic appears to be even more problematic. In 2014, Albania reflected not only a low level of GEW compared to 2006,5 but also a poorer performance compared with many other countries. ${ }^{6}$ In this paper gender equity measured in the four areas mentioned above as a single coefficient will be known as the Combined

\footnotetext{
1 The latest report of the World Economic Forum (WEF), presented in 2014, observed GenderEquity in 142 countries.

${ }^{2}$ See World Economic Forum 2006-2014 Reports by Ricardo Hausmann, LauraD. Tyson, Yasmina Bekhouche, and Saadia Zahidi.

${ }^{3}$ In 2006, the coefficient of the CGE in Albania was 0.6607 and in 2014 it was 0.6870 . So, Albania has a slight improvement the CGE lev el with +0.0263 , or $3.98 \%$.

${ }^{4}$ In 2006, among the 115 countries surveyed, Albania was ranked the 61 st and left behind $47 \%$ of the countries, while in 2014 , among the 142 countries surveyed, Albania was ranked the $83 \mathrm{~d}$ and left behind $42 \%$ of the countries observed. This shows that Albania has performed $w$ orse than at least $5 \%$ of countries observed which had had a low coefficient of the CGE before.

${ }^{5}$ In 2006 the coefficient of GEW in Albania w as 0.6610 , whereas in 2014 it was 0.6530 . thus Albania reflects a decline, though a s light one, of the CGE with -0.0080 , or $1.21 \%$.

${ }^{6}$ In 2006, among the 115 countries surveyed Albaniawas ranked the 38 th and left behind $67 \%$ of the countries, while in 2014 , among 142 countries surv eyed Albania was ranked the 78 th and left behind only $45 \%$ of the countries surveyed. Thus, Albania's performance was weaker than at least $22 \%$ of the surv eyed countries which previously had a bad coefficient of the GEW compared to that of Albania.
} 
Gender Equity (CGE), while gender equity measured in terms of employment and labor relations will be known as Gender Equity at Work(GEW).

Based not only on the level and tendencies that were observed in the case of GEW and not only when analyzed as a separate area but also when compared with CGE, two questions can be raised about GEW. What could explain the dy namics that characterizes GEW, both as level or as tendency? What could explain the significant increase of the observed GEW -whether in the period of 2008-2011, or in 2014? What about the significant decline seen in the period 2011-2013, what can explain it? To what extent can either the decline or increase of GEW be explained with the role of the legal factors?

These questions are the focus of this paper which analyzes the GEW dynamics in Albania from a legal perspective. This paper is structured in the following way. The next section analyzes gender equity at work the role, and influence of the legal instruments in Albania The second section analyzes the facts observed in the Albanian reality in the periods 2008-2011 and 2011-2013. The analysis aims at shedding light on the degree of the responsibility of the legal factors in Albania for the upward and downward dynamics observed with regard to GEW. This paper closes with conclusions. Based on the analysis of concrete cases related to GEW, the conclusions will provide an explanation whether the observed dynamics should be attributed to legal factors or other factors.

\section{A brief overview of the literature.}

Many researchers, despite their perspective of the analysis, consider gender equity very important because of its impact. From a social standpoint, gender equity affects the quality of life of people, the state of social welfare, health insurance, the capacity of the state to provide social assistance, or human capital, ${ }^{1}$ and from an economic perspective, it affects the quality of human resources, labor cost, business development, or relations with customers. ${ }^{2}$ Gender equity in the private sector affects the recruitment of talent, ${ }^{3}$ business performance, or quality of customer service, ${ }^{4}$ while in the context of work, it affects economic growth, worker productivity, human resources, business development, tax revenues to the state budget, or the social security system. ${ }^{5}$

There are also many scholars who associate the degree of gender equity to the role of national or international legal factors, which consist in the role of instruments, actors, and legal institutions. At the international level, legal instruments include

\footnotetext{
${ }^{1}$ Karen Kraal, John Wrench, Judith Roosblad and Patrick Simon (2009), "The ideal of equal opportunities and the practice of unequal chances," pp. 10-11, in Karen Kraal, Judith Roosblad, and John Wrench (eds) (2009), Equal Opportunities and Ethnic Inequity in European Labor Markets: Discrimination, Gender, and Policies of Diversity, Amsterdam University Press.

${ }^{2}$ Lew is, S. and J. Lewis (1996). The work-family challenge. London: Sage Publications; Brekel, C. van den, M. van Klaveren and K. Tijdens. (1999), The Absence of Women in the ICT-sector.

${ }^{3}$ Hsieh, C. T., E. Hurst, C. I. Jones, and P. J. Klenow (2012), The allocation of talent and US economic growth, unpublished manuscript.

${ }^{4}$ Carter, D., B. Simkins, and G. Simpson (2003), "Corporate governance, board diversity, and firm value," Financial Review, Vol. 38, No. 1, pp. 33-53; McKinsey and Company (2008), "A business case for women," McKinsey Quarterly, September; Adams, R. B. and D. Ferreira (2009), "Women in the boardroom and their impact on governance and performance," Journal of Financial Economics, Vol. 94, No. 2, pp. 291-309; Tejesen, S., R. Sealy and V. Singh (2009), "Women directors on corporate boards: A review and researchagenda," Corporate Governance: An International Review, Vol. 17, No. 3, pp. 320-337; Adams, R. B. dhe P. Funk (2009), "Beyond the glass ceiling: Does gender matter?", UPF Working PaperSeries, ECGI - Finance Working Paper, No. 273/2010 European Comorate Governance Institute, Brussels, available at http://ssrn.com. abstract=1475151; Dezso, C. L. and D. G. Ross (2011), "Doesfemale representation in top management im prove firm performance? A panel data investigation," Robert $H$. Smith School Research Paper, No. RHS06-104, available at http://ssrn.com/abstract=1088182; Nielsen, S. and M, Huse (2010), "The contribution of women on boards of directors: Going beyond the surface,"Corporate Governance: An International Review, Vol. 18, No. 2, pp. 136-148.

${ }^{5}$ Karen Kraal, John Wrench, Judith Roosblad and Patrick Simon (2009), "The ideal of equal opportunities and the practice of unequal chances," p. 24 in Karen Kraal, Judith Roosblad, and John Wrench (eds) (2009) Equal Opportunities and Ethnic Inequity in European Labor Markets: Discrimination, Gender, and Policies of Diversity, Amsterdam University Press.
} 
the treaties,,$^{1}$ conventions, ${ }^{2}$ norms, statements and recommendations, ${ }^{3}$ while actors and institutions include international courts and organizations, international committees and commissions, and national states members of international organizations. ${ }^{4}$ In a national level, legal instruments include the constitution, national laws, codes, and governmental policies, ${ }^{5}$ whereas actors and institutions include the legislative and parliamentary commissions, the executive and public agencies, as well as the judicial system represented by the courts and the judges. ${ }^{6}$ Those researchers who highlight the role of the legal factors, attribute the positive impact and the contribute in the improvement and increase of gender equity to such factors. ${ }^{7}$ There are researchers who give precedence to the international instruments, ${ }^{8}$ because they see them as a reference point for the states in formulating their national instruments. Other researchers emphasize the role of actors, giving priority especially to the national actors, and specifically to the legislative,${ }^{9}$ as the role and impact of international instruments is likely to be greater when national states reflect them in the changes that the national parliament makes in the legislation on gender equity, compared to cases when the national states do not express the will to change legislation. There are also some who bind the effect of legal factors on gender equity with the clear or unclear definition of gender equity standards, ${ }^{10}$ the reflection of these standards in national instruments, the acceptance or lack of acceptance of the gender equity standards from the national actors, ${ }^{11}$ respect or lack of respect for these standards by the national actors, as

${ }^{1}$ Emilie M Hafner-Burton and Kiy oteru Tsutsui (2007), "Justice Lost! The Failure of International Human Rights Law to Matter Where Needed Most," Journal of Peace Research, Vol. 44, pp. 407-425.

${ }^{2}$ Suzanne Zw ingel (2005), How do international women's rights norms become effective in domestic contexts? An analysis of the Convention on the Elimination of All Forms of Discrimination against Women (CEDAW), Doctoral Dissertation, Ruhr-University Bochum, http://w wwbrs.ub. ruhrunibochum.de/netahtml/HSS/Diss/ZwingelSusanne/diss. pdf; Beth A. Simmons (2009), Mobilizing for Human Rights, Cambridge: Cambridge University Press; Andrew C. Byrnes and MarshaFreeman (2012), "The Impact of the CEDAW Conv ention: Paths to Equity," UNSW Law Research, Paper No. 2012-7, February 20, 2012, p. 5.

${ }^{3}$ Liu Dongxiao and Elizabeth Heger Boyle (2001), "Making the Case: The Women's Convention and Equal Employment Opportunity in Japan" International Journal of Comparative Sociology, Vol. 42, pp. 389-404; Petrice R. Flowers (2009), "Gender Equity and Women's Employ ment," Chapter 4, pp. 69-112, in RefuGEWs, Womenand Weapons: International Nom Adoption and Compliance in Japan, Stanford: Stanford Univ ersity Press.

${ }^{4}$ International Law Association (2002), Report of the Seventieth Conference, New Delhi, pp. 507-555; International Law Association (2002), Final report on the impact of the United Nations treaty bodies on the work of national courts and tribunals; International Law Association (2004), Report of the Seventy-First Conference, Berlin, pp. 621-687; Emerton, Robyn. and Kristine Adams, Andrew Byrnes, Jane Connors (2201), International Women's Rights Cases, RoutledgeCavendish; Andrew C. Bymes and Marsha Freeman, "The Impact of the CEDAW Conv ention: Paths to Equity," UNSW Law Research, Paper No. 2012-7, February 20, 2012, p. 1.

5 llana Landsberg-Lewis (eds.) (1998), Bringing equity home: Implementing the convention on the elimination of all forms of discrimination against women, CEDAW, UNDP for Women, New York; Visser, J., T. Wilthagen, R. Belzer and E. Koot-van der Putte (2004), "The Netherlands: from Atypicality to a Typicality", in S. Sciarra, P. Davies and M. Freedland (eds.), Employment Policy and the Regulation of Part-time Work in the European Union, A Comparative Analysis, Cambridge University Press, Cambridge, pp. 190-223. ${ }^{6}$ Andrew C. Byrnes and Marsha Freeman, "The Impact of the CEDAW Convention: Paths to Equity," UNSW Law Research, Paper No. 2012-7, February 20, 2012, p. 4; OECD (2012), Partl, Chapter 3, "Embedding gender equity in Public Policy," pp. 37-44, in Closing the gender gap: Act now, OECD, Paris, France.

${ }^{7}$ Andrew C. Byrnes and Marsha Freeman, "The Impact of the CEDAW Conv ention: Paths to Equity," UNSWLaw Research, PaperNo. 2012-7, February 20, 2012, p. 2.

${ }^{8}$ Oona Hathaw ay (2002), "Do Human Rights Treaties Make a Difference?" Yale Law Journal, Vol. 112, p. 1935; Ryan Goodman and Derek Jinks (2003), "Measuring the Effects of Human Rights Treaties," European Journal of International Law, Vol. 14, pp. 171-183; Varun Gauri (2011), "The Cost of Complying with Human Rights Treaties: the Convention on the Rights of the Child and Basic Immunization," Review of International Organizations, Vol. 6, pp. 33-56; Andrew C. Byrnes and MarshaFreeman, "The Impact of the CEDAW Conv ention: Paths to Equity," UNSW Law Research, Paper No. 2012-7, February 20, 2012, pp. 5-6.

${ }^{9}$ Andrew C. Byrnes and Marsha Freeman, "The Impact of the CEDAW Conv ention: Paths to Equity," UNSWLaw Research, PaperNo. 2012-7, February 20, 2012, pp. 3-4.

${ }^{10}$ By rnes, Andrew (1997): "Human Rights Instruments," in pp. 50-55, in Andrew Byrnes, Jane Connors, and Lum Bik (eds), Advancing the human rights of women: Using international human rights standards in domestic litigation, the Centre for Comparative and Public Law, the University of Hong Kong; Goonesekere, Savitri (2000) "Gender-specific Norms and Standards," in A right-based approachto realizing gender equity, Paper, UN Division for the adv ancement of w omen;

${ }^{11}$ Flavia Agnes (1997), "The domestic application of international human rights norms relevant to w omen's human rights: Strategies of law reform in the Indian context," pp. 101-113, in Andrew Bymes, JaneConnors, and Lum Bik (eds), Advancing the human rights of women: Using international human rights standards in domestic litigation, the Centre for Comparative and Public Law, the University of Hong Kong. 
well as the implementation of decisions in cases of conflicts with gender character by the national institutions, the society in general, or by the specific segments and individuals. ${ }^{1}$

This paper examines gender equity at work and its dynamics based on three indicators: 1) participation at work, 2) working positions, and 3) salary. Departing from the coefficient that the report of the World Economic Forum (WEF) attaches to the gender equity at work in Albania, the latter is characterized by an increase over the period of 2008-2011, a decline during the period of 2011-2013 and another increase in 2013-2014. The INSTAT data provide a more detailed picture of the dy namics of GEW in three measuring indicators. In the period of decline in 2011-2013, GEW regarding participation at work reflected deterioration either as level or as tendency. In 2013 the level of gender gap regarding participation at work exceeds $20 \% .^{2}$ In the period of decline in 2011-2013, GEW in Albania in terms of the range of positions and sectors that employ women they appeared to be either stable or worsened. According to INSTAT data, men dominate over women not only from the number of positions and sectors occupied by them, ${ }^{3}$ but also in the percentage within a specific sector. ${ }^{4}$ This paper tries to see if the increasing or decreasing dynamics of the level of GEW that are observed in Albania in the periods of 2008-2011, 2011-2013, and 2013-2014, can be explained by the role of the internal Albanian legal factors. The extent at which the legal factors have determined the dynamics of GEW in Albania reflects the role and degree of influence of the legal instruments, the legislative, the executive, and judiciary. What weobserved in the case of Albania are two realities: 1) the availability of the necessary tools guaranteeing the GEW and 2) the active role of the legislature, the judiciary and the executive.

\subsection{Gender equity at work, the role, and influence of the legal instruments in Albania}

Two facts are observed in the case of Albania. Firstly, that Albania possessed the national instruments that protect GEW even before 2006. Table 6 summarizes all national instruments, according to the legal hierarchy, available to the protection of gender equity at work.

\section{TABLE 6 - National Instruments Available to GEW}

\begin{tabular}{|l|l|}
\hline Instrument & Articles that cover the GEW \\
\hline The Constitution of the Republic of Albania & $17,18,42,43,49,54 / 1,101,131 / \mathrm{a} / \mathrm{f}, 132,134 / \mathrm{g}$, \\
\hline The Labor Code & $105 / \mathrm{a}, 107,141,143,144,146 / 1,202 / 2$, \\
\hline Administrative Procedure Code & $116 \mathrm{c}, 117$ \\
\hline Civil Procedure Code & $31,32,36,47,153,154,610$ \\
\hline Civil Code & 608,625 \\
\hline
\end{tabular}

Secondly, we note that during the period 2006-2014, Albania has made efforts to approximate and match its instruments with international standards on a number of cases. The first case is the Constitution of the Republic of Albania. It reflects its tendency to be in line with the European Convention on Human Rights in its three articles. Article 17/2 evokes the ECHR giving it constitutional status in our domestic law. Article 18 establishes the principle of equity and non-discrimination,

\footnotetext{
${ }^{1}$ P.N. Bhagw ati (1997), "Creating a judicial culture to promote the enforcement of w omen's human rights," pp. 20-26, in Andrew Bymes, Jane Connors, and Lum Bik (eds), Advancing the human rights of women: Using international human rights standards in domestic litigation, the Centre for Comparative and Public Law, the University of Hong Kong.

${ }^{2}$ In 2013 , participation of w omen at w ork is $50.1 \%$ compared to $70.2 \%$ of men, thus $-20.1 \%$. See Institute of Statistics in Albania (2014), "Active Economic Population," p. 61, in Women and Men in Albania, INSTAT, Albania.

${ }^{3}$ Women are mainly employed in the public health and education, or in the priv ate sector of agriculture and are almost inconsiderable percentage in the sectors of construction, transport, or telecommunications. See Statistical Institute of Albania (2014), "Employment structure by gender and economic activity" p. 72 Women and Men in Albania, INSTAT, Albania.

${ }^{4}$ In specific sectors, the gender gap is higher, in the Construction and Transport in which men occupy $97.3 \%$ and women occupy $2.7 \%$, or differently, w omen have a difference of $-94.7 \%$ with men; in Telecommunications, where men occupied $80.5 \%$ and $19.5 \%$ women, or differently, women havea difference of $-61 \%$ with men; in education, wherewomen occupy $68.2 \%$ and men $31.8 \%$, women dominate he sector therefore with $+36.4 \%$, and in Health Care, where women occupy $72.4 \%$ and men $27.6 \%$, women dominate the sector with + $44.8 \%$. See Statistical Institute of Albania (2014), "Employment structure by gender and economic activity" p. 72 in Women and Men in Albania, INSTAT, Albania.
} 
determining that "everyone is equal before the law, and no one can be discriminated for such reasons as gender, race, ethnicity, political opinions, religious or philosophical beliefs, economic, educational, social or parentage." While, Article 116 stipulates the prevalence of the international law ratified by the Republic of Albania on domestic laws.

The second case of approximation with the standards of international instruments is the Labor Code of the Republic of Albania. Approved by Law 7961, on 12 July 1995, it is based on respect for international standards of labor law protecting the rights and freedom of the parties and two changes were made: Law Nr.8085, on 12 March 1996 and Law no. 9125, on 29 July 2003 . Article 9 determines the prohibition of any discrimination in employment. Article 146/2 stipulates the right of the employee to sue the employer if the contract is terminated without reasonable cause but the employer is released from the burden of proof in order to prove discrimination only if it was proven the exemption based on gender, race, religion, ethnicity, language, political beliefs, economic status, as well as the social, educational status and parentage. There have been several attempts to improve the approximation of the Labor Code with the standards of international instruments. Another attempt is the Albanian Constitutional Court in 2007. ${ }^{1}$ In parallel opinion of the decision, expressed by member Fehmi Abdiu, it was suggested that Article 146 of the Labor Code be aligned with EU legislation. ${ }^{2}$ Alignment has to do with the issue of burden of proof for discrimination and specifies three things: 1) that the employee who claims discrimination is not obliged to prove discrimination, but only to provide the court the necessary doubt that discrimination has occurred, 2) if the employer cannot prove his absence, the court must decide in favor of the employee, and 3) that after presumption for discrimination by the employee, the employer is to prove that the employee has not been discriminated. Therefore, the employer has the burden of proof and the employee only needs to create the necessary doubt to the judge that there was discrimination without being obliged to prove it.

Other attempts to approximate are the recommendations of the Commissioner for Protection from Discrimination in 2012 for some changes in the Labor Code. ${ }^{3}$ In the recommendations three suggestions were made: 1 ) to reformulate the concept of "discrimination" adding causes of discrimination, including sexual orientation and gender identity, according to Law 10221/2010 "On protection from discrimination"; 2) to include other forms of discrimination as "instruction to discriminate", "concern", "victimization", "discrimination by association" and "denial of reasonable adjustment"; and 3) to prescribe the obligation of the employer to ensure equal employment.

The third case is that of the Administrative Procedure Code. Approved by Law no. 8485, in May 12, 1999, the Code establishes the principle of equity as one of the basic principles of the functioning of the public administration. Attempts for a new bill aimed at aligning it with EU standards and CEDAW. The Commissioner of Protection from Discrimination has offered three amendments: ${ }^{4}$ 1) definition of equity and non-discrimination as basic principles of activity of any public body; 2) harmonization of the causes of discrimination in Article 1 of Law no. 10-221, 4 February 2010, "On protection from discrimination;" and 3) regulating the burden of proof in discrimination cases in accordance with the EU directives and CEDAW. Referring to the EU Directive 97/80, ${ }^{5}$ to approximate the Code of Administrative Procedure with the acquis communautaire of the EU, the Commissioner has suggested removing the burden of proof for the plaintiff in the case of discrimination on grounds of sex and gender through a section that stipulates that in cases where the plaintiff presents evidence of discrimination, or presumes discrimination, the defendant is obligated to prove that the facts do not constitute discrimination. The Commissioner has suggested that in the case of administrative proceedings the burden of proof should go to the public administration body.

The fourth case is that of the Civil Procedure Code of the Republic of Albania. In Article 12 provides that the burden

\footnotetext{
${ }^{1}$ Constitutional Court of Albania, Decision No. 33, 12 September 2007, the case Joint Chambers of the Supreme Court vs. Assembly of the Republic of Albania and the Gov ernment of the Republic of Albania.

${ }^{2}$ European Commission, Directive nr. 78/2000, "On the creation of a regulatory framefor equal treatment in employment relationships."

${ }^{3}$ Commissioner of protection against Discrimination, Letter Nr. 360, Prot, Dated on 14 Sep. 2012

${ }^{4}$ Commissioner for Protection against Discrimination, Letter no. 692/1, 30 December 2013, the Ministry of Justice; Commissioner for Protection against Discrimination, Letter no. 894/1 Prot, 24 October 2014 addressed to Mr. Fatmir Xhafaj, Chairman of the Com mittee on Legal Affairs, Public Administration and Human Rights, near Parliament.

${ }^{5}$ The Directive states that "Member States shall take such necessary measures, in accordance with their national legal systems, to ensure that, when persons who consider that he has becomean unfair because of the failure of the principle of treatment equal, brought before a court or other competent authority, facts from which it may be presumed that there has been direct or indirect discrimination, it will be the duty of the defendant to prove that there was no violation of the principle of equal treatment. "
} 
of proof for existence of irrational causes of settlement labor contract is left to the plaintiff. ${ }^{1}$ In an effort to align the Code with the EU Directives on equal treatment and non-discrimination, ${ }^{2}$ and based on the jurisprudence of the ECJ, the Commissioner has suggested an article which states that during a civil proceeding, the burden of proof is transferred from the plainiff to the party sued for discrimination (defendant). ${ }^{3}$

Thus, the dynamics of the GEW are observed in relation to the instruments available to guarantee GEW what is seen is a contradiction between the level and trends of GEW in Albania and the range of instruments available to GEW. Although GEW protection instruments have existed before 2006 and during the period between 2006 to 2014 they were characterized by the tendency of expanding their range and approximation to the standards of international instruments, the GEW level, as it was recorded by the WEF, has been low and the general trend of GEW has been the decline if the level of GEW. Given the fact that the "instrument" factor generally displays a positive role and influence in favor of guaranteeing the GEW, what can be said is that apparently, the number of the instruments available to GEW has played no significant role in determining the level and trends that GEW has registered in Albania in the period of 2006-2014.

\subsection{Gender equity at work, the role, and influence of the legislature in Albania}

Even in the case of the legislative activity, expressed in laws that it adopted, two realities were noticed. First, the Albanian legislature has been active in enacting laws which include and cover, through specific sections, even the GEW problems, either before 2006 or during the period of 2006-2014. Table 7 summarizes the main laws approved by the legislative before and after 2006.

\section{TABLE 7: LAWS OF GEW TO BE ADOPTED BY THELEGISLATIVE}

\begin{tabular}{|c|c|}
\hline & LEGISLATIVELAWS BEFORE2006 \\
\hline 1991,08 August & $\begin{array}{l}\text { Law no. 7510, "On the access of the Republic of Albania in the International Cov enant on Civil and } \\
\text { Political Rights" }\end{array}$ \\
\hline 1991, 08 August & $\begin{array}{l}\text { Law no. 7511, "On the access of the Republic of Albania in the International Cov enant on Economic, } \\
\text { Social and Cultural Rights" }\end{array}$ \\
\hline 1993, 09 Nov ember & $\begin{array}{l}\text { Law no. 7767, "On the access to the Conv ention 'on the Elimination of All Forms of Discrimination } \\
\text { against Women" }\end{array}$ \\
\hline 1996, 31 July & $\begin{array}{l}\text { Law no. 8137, "On the ratification of the European Convention for the Protection of Human } \\
\text { Rights and Fundamental Freedoms" }\end{array}$ \\
\hline \multirow[t]{2}{*}{ 2003, 17 April } & $\begin{array}{l}\text { Law no. 9052, "On the ratification of the Optional Protocol to the Conv ention on the Elimination of All } \\
\text { Forms of Discrimination against Women" }\end{array}$ \\
\hline & LEGISLATIVELAWS DURING 2006-2014 \\
\hline 2008, 24 July & Law no. 9970 "On Gender Equity in Society" \\
\hline 2010, 04 February & Law no. 10-221, "Protection from Discrimination" \\
\hline
\end{tabular}

The second reality is the tendency observed in the Albanian legislature to legislate, which aligns GEW handling with the standards of international laws and instruments. Thus, all the laws issued before 2006, are formulated in accordance with the standards set by international pacts and conventions. Law No. 7510 reflects the standards of the International Convention on Civil and Political Rights, ${ }^{4}$ Law No. 7511 reflects the standards of the International Convention on Economic,

${ }^{1}$ Code of Civ il Procedure, Article 12, stipulates: "The party that claims a right, has no obligation, in accordance with the law , to prove the facts on which he/she bases his/her claim."

${ }^{2}$ European Council Directive 97/80; European Parliament and European Council Directive 2006/54 / EC, 5 July 2006, "On the principle of equal opportunities and equal treatment of men and w omen in matters of employment and occupation."

${ }^{3}$ Commissioner for Protection against Discrimination, Letter no. 294, Prot 10 March 2014 to the Minister of Justice Nasip Naco.

${ }^{4}$ From the ICCPR, the Albanian legislature has incorporated into its law Article 2 that establishes the obligation of States parties "to ensure that all citizens are subject to the protection of the rights provided for in this Convention without distinction of race, color, sex, 
Social and Cultural Rights, ${ }^{1}$ Law No. 7767 reflects the standards of CEDAW, ${ }^{2}$ and Law No. 8137 reflects the standards of the European Convention for the Protection of Human Rights and Fundamental Freedoms. ${ }^{3}$

Even the laws enacted by the legislature in the period 2006-2014 devote the same attention to international standards, and their tendency is to be more in line with the spirit of the instruments and international laws. Law 9970 "On Gender Equity in Society" has taken into account the standards of CEDAW. ${ }^{4}$ The law hat best expresses the tendency of the Albanian Legislature to legislate in accordance with the standards of instruments and international law is Law No. 10-221 "On Protection from Discrimination." This law guarantees the right of every person to equity before the law, protection of equity by the law, equity of opportunities and possibilities to exercise the individual rights and freedoms, provides protection and regulates the implementation and observance of the principle of equity in connection with an extensive list of causes, and also provides effective protection against discrimination. ${ }^{5}$ Above all, this law establishes the institution of the Commissioner for Protection from Discrimination (CPD). ${ }^{6}$ Its formulation and content was made $\mathrm{n}$ accordance with the standards of a number of international factors and documents,: 1) in the European Convention of Human Rights, ${ }^{7}$ with CEDAW, ${ }^{8}$ with the standard and handling of ECHR, ${ }^{9}$ as well as will the ascquis and the directives of EU. ${ }^{10}$

Considering the feature of the Albanian Legislature to legislate in accordance with the standards of international instruments, it seems contradictory that although laws enacted have favored the guarantee of GEW, the low level and the

language, belonging or regional political, ethnicity, social origin, property or birth status "and Article 26, which provides that" to all people are equal before the law, are entitled to the equal protection law without any discrimination, and the law shall prohibit any discrimination and guarantees for the whole, the equal and effective protection against any discrimination."

${ }^{1}$ By this pact, the Albanian legislature has agreed to incorporate in its law assertion that States Parties shall ensure that the economic, social and cultural rights enunciated in the present Covenant will be exercised without discrimination and awareness of some of the rights enshrined in the Conv ention such as the right to w ork, trade union rights, the right to social security, or the right to education. 2 The Albanian Legislativ e has agreed to incorporate the law retains its attitude tow ards all forms, direct or indirect, discrimination and disrespect of gender equity and ensuring protection against them.

${ }^{3}$ The Albanian Legislative has agreed to incorporate in its law recognition of the principle of non-discrimination, expressed in Article 14 that the "prohibition of discrimination", closely discrimination connection with the rights set out in the Articles of the Conv ention and Article 1 of Protocol No. 12 which prohibits discrimination in cases where a person is discriminated against in the enjoyment of any right or benefit under national legislation.

${ }^{4}$ This law has incorporated the CEDAW settings for particular discrimination (Article 4) and the prohibition of discrimination on grounds of sex (Article 6). The law specifically provides Albanianstate obligations in relation to gender equity in political representation and public life, representation at the national lev el, citizenship, trafficking and prostitution, equity in education, employment, health care and reproductiv e health, economic and social welfare, equity before law, and equity in marriage and family.

${ }^{5}$ Article 1 prov ides specific causes which provides protection butalso protection "for any other reason." Article states that "the law gov erning the application and observance of the principle of equity with regard to sex, race, color, ethnicity, language, gender identity, sexual orientation, political opinions, religious or philosophical beliefs, economic, educational or social, pregnancy, parentage, parental responsibility, age, family or manital, marital status, residence, health status, genetic predispositions, disability, belonging to a particular group, or for any other reason."

${ }^{6}$ Commissioner for Protection against Discrimination qualified as a legal, public, independent person, responsible for protection from discrimination, and covers discrimination both in the public sector and the private one, such as in relation to groups and institutions as well as in relations among particular individuals.

${ }^{7}$ The law incorporates all the causes listed in Article 14 of the ECHR as w ell as general comment 18 of the Committee of Human Rights for discrimination by considering non-discrimination, equity before the law and equal protection of the law without discrimination as core principles concerning the protection of human rights; and accepted that as a collaborative state, it will take positive measures to eliminate conditions that cause or foster discrimination prohibited by the Convention.

${ }^{8}$ Article 3 of Law 10-221 "Protection against Discrimination" reflects the standards of CEDAW

${ }^{9}$ Article 1 of Law 10-221 takes into account the relation betw een the definition giv en by Article 14 of ECHR about causes of discrimination and interpretation of discrimination by the ECHR as an expression of the differences that are based on a personal characteristic or what distinguishes a person or group of persons from others.

${ }^{10}$ Four EU directiv es in the field of non-discrimination include: 1) Council Directive 2004/43 / EC, 29 June 2000, on "The implementation of the principle of equal treatment betw een persons irrespective of racial or ethnic origin;" 2) of Council Directive 2000/78 / EC, 27 Nov ember 2000, to "define a general framework for equal treatment at w ork;" 3) Council Directive2004/113 / EC, 13 December 2004, on "The implementation of the principle of equal treatment betw een men and women and the opportunity to be supplied with goods and services",4) Directive of the European Parliament and of the Council 2006/54 / EC, 5 July 2006, "On the implementation of the principle of equal opportunity and equal treatment of men and w omen in matters of employment and occupation" Direct ex pression of compliance of Law 10-221 with these directives is shifting the burden of proof from the employ ee to the employer in Article 36, point 6. 
declining trends of the latter, however, do not display and reflect any positive impact from the role and influence of the Legislature.

\subsection{Gender equity at work: the role, and influence of the executive in Albania}

In the case of the Executive three observations apply. First, we observe a less active role compared to that of the legislature and the Albanian judiciary, either before or after 2006. The normative acts of the Council of Ministers are missing, or are very few in number. Before 2006, an Act of the Council of Ministers concerns the relationship at work is DCM no.360, dated 14 July 2000, "On release from civil service." This act establishes the circumstances of termination of employment for those working in the Civil Service and Public Administration. During the period 2006-2014, the next act of the Council of Ministers is the Normative Act No. 5, September 30, 2013, "On amendments to Law no. 152/2003, 'for civil servants. "And at that time the Council of Ministers has requested and approved by the Albanian Legislature Law no. 178, 18 December 2014, "On amendments and additions to Law no. 152/2013 "for civil servants."

Secondly, the acts and decisions of the Council of Ministers in their formulation are not characterized by the same concern for compliance with the standards of international instruments, as observed in the case of national instruments, the laws of the Legislature, or the decisions of the Albanian judiciary. Consequently, acts or laws initiated by the executive for approv al by the parliament have not always been in the spirit of international instruments and standards. In 2014, the Constitutional Court decided, in Decision No. 5, dated 5 February 2014 to reject and abolished as incompatible with the Constitution and international standards the Normative Act no. 5 of Council of Ministers, dated 30 September 2013 "OnAmendments to the Law Nr.152 / 2013 'On the Civil Servant' " as well as Law No. 161/2013 "Onapproval of the normative act No. 5, dated 30 September 2013 "On Amendments to the Law Nr.152 / 2013" 'On the civil servants' " initiated by the Council of Ministers and approved by the Legislature. ${ }^{1}$

Thirdly, the very role and influence of the executive in relation to GEW appears to be problematic: Acts and Laws initiated by the Council of Ministers coincide with periods of decline of the GEW such as the Normative Act No. 5, as well as the Law approved by the parliament for this act, coincide with the period of 2011-2013 when the WEF has recorded and in Albania a low level and a decline trend of the of level of GEW.

Therefore, in the case of the activity of the executive, although the latter appears less active, it can be said that its role and its impact on the level and trends of the GEW in Albania may be considered either problematic or completely insensitive.

\subsection{Gender equity at work: the role, and influence of the judiciary in Albania}

Even in the case of the role and influence of the Albanian judiciary three realities can be observed. The first reality shows an active role of the judiciary during the period of 2006-2014 in judgment and decision-making process on cases with the object of work relations and gender equity at work. Table 8 lists the litigated cases in three periods: 2006 to 2010, when WEF records an increase of the level of GEW; 2011-2013 in which WEF records a decline of the GEW level; and for 2014, in which WEF records an increase in the GEW level, although the GEW level in 2014 does not exceed the level of GEW that WEF attaches to Albania in 2006.

\section{TABLE 8: DISCRIMINATION CASES OF GEW JUDGED BY THE ALBANIAN JUDICIARY}

\begin{tabular}{|l|l|l|l|}
\hline \multicolumn{2}{|l|}{ Period 2006 - 2010 (characterized by increasing the lev el of GEW) } & Work contract \\
\hline 2006, 12 December & Durres District Court & $\begin{array}{l}\text { Decision no. 2918 - Trupja vs. Maritime } \\
\text { Directorate }\end{array}$ & $\begin{array}{l}\text { Decision no. 33 - Joint College of the Supreme } \\
\text { Court (JCSC) vs. Executive/ Legislative }\end{array}$ \\
\hline 2007,12 September & Constitutional Court & before the Law \\
\hline
\end{tabular}

\footnotetext{
${ }^{1}$ Constitutional Court, decision No. 5, dated February $5^{\text {th }} 2014$, on the issue "36 deputies of the Albanian Parliament against the Council of Ministers of the Republic of Albania and the Republic of Albania Assembly. The Constitutional court of the Republic of Albania consisted of Bashkim Dedja (Chairman) and Vladimir Kristo Sokol Berberi, Altina Xhoxhaj, Fatmir Hoxha, Gani Dizdar, Besnik Imeraj Fatos Lulo, Vitore Tusha (members)
} 


\begin{tabular}{|c|c|c|c|}
\hline 2007, 03 December & Court of Appeal Durres & Decision no. 540 - Trupja v s. Maritime Directorate & Work contract \\
\hline 2008, 21 January & Durres District Court & Order no. 36 - Trupja vs. Maritime Directorate & $\begin{array}{l}\text { Enforcement of } \\
\text { Decision }\end{array}$ \\
\hline 2008, 07 April & Bailiff Office in Durres & Request-Trupja vs. Maritime Directorate & $\begin{array}{l}\text { Enforcement of } \\
\text { Decision }\end{array}$ \\
\hline 2008, 21 April & Bailiff Office in Durres & Letter no. 864 - Trupja v s. Maritime Directorate & $\begin{array}{l}\text { Enforcement of } \\
\text { Decision }\end{array}$ \\
\hline 2008,05 June & Durres District Court & Decision Nr.1714 - Sinani vs. UAMD & Work contract \\
\hline 2009, 22 April & The Court of Shkodër & $\begin{array}{l}\text { Decision no. } 1057 \text { - Semanaj vs. the Department } \\
\text { of Public Health of Malesia e Madhe }\end{array}$ & Work contract \\
\hline 2009,16 July & Court of Appeal of Durres & Decision no. 305 - Sinani v s. UAMD & Work contract \\
\hline 2010, 11 January & $\begin{array}{l}\text { Court of Appeal of } \\
\text { Shkodra }\end{array}$ & $\begin{array}{l}\text { Decision no. } 5 \text { - Semanaj v s. the Department of } \\
\text { Public Health of Malesia e Madhe }\end{array}$ & Work contract \\
\hline 2010, 25 Nov ember & Civ il Service Commission & $\begin{array}{l}\text { Decision no. } 127 \text { - Paluka vs. the Ministry of } \\
\text { Agriculture }\end{array}$ & Work contract \\
\hline 2010, 27 December & Bailiff Office in Durres & Letter no. 184/10 - Trupja v s. Maritime Directorate & Work contract \\
\hline \multicolumn{4}{|c|}{ Period 2011 - 2013 (characterized by a decreased level of GEW) } \\
\hline 2011, 01March & Court of Appeal of Tirana & $\begin{array}{l}\text { Decision no. } 23 \text { - Paluka vs. the Ministry of } \\
\text { Agriculture }\end{array}$ & Work contract \\
\hline 2011, 24March & Court of Appeal of Tirana & $\begin{array}{l}\text { Decision No.28-Paluka vs. the Ministry of } \\
\text { Agriculture }\end{array}$ & $\begin{array}{l}\text { Enforcement of } \\
\text { Decision }\end{array}$ \\
\hline 2011, 11 April & Bailiff Office in Tirana & $\begin{array}{l}\text { Letter no. 4386-Paluka vs. the Ministry of } \\
\text { Agriculture }\end{array}$ & $\begin{array}{l}\text { Enforcement of } \\
\text { Decision }\end{array}$ \\
\hline 2011, 16 May & Prosecution Durres & Denunciation - Trupja v s. Maritime Directorate & $\begin{array}{l}\text { Enforcement of } \\
\text { Decision }\end{array}$ \\
\hline 2011, 13 June & Bailiff Office in Tirana & $\begin{array}{l}\text { Letter no. 6552- Paluka vs. the Ministry of } \\
\text { Agriculture }\end{array}$ & $\begin{array}{l}\text { Enforcement of } \\
\text { Decision }\end{array}$ \\
\hline 2011, 13 June & Bailiff Office in Durres & Letter no. 09/118 - Trupja v s. Maritime Directorate & $\begin{array}{l}\text { Enforcement of } \\
\text { Decision }\end{array}$ \\
\hline 2011,23 June & $\begin{array}{l}\text { College of the Supreme } \\
\text { Court }\end{array}$ & $\begin{array}{l}\text { Decision no. 986-Paluka vs. the Ministry of } \\
\text { Agriculture }\end{array}$ & Work contract \\
\hline 2011, 28 July & Bailiff Office in Tirana & $\begin{array}{l}\text { Letter no. 8314-Paluka vs. the Ministry of } \\
\text { Agriculture }\end{array}$ & $\begin{array}{l}\text { Enforcement of } \\
\text { Decision }\end{array}$ \\
\hline 2011, 25 August & Bailiff Office in Durres & Decision no. 09/118- Trupja vs. Maritime directorate & $\begin{array}{l}\text { Enforcement of } \\
\text { Decision }\end{array}$ \\
\hline 2012, 01 June & the Court of Tirana & Decision no. 3331 - Kastoria v s. Arts Academy & Work contract \\
\hline $\begin{array}{l}2011,08 \\
\text { September }\end{array}$ & Bailiff Office in Tirana & $\begin{array}{l}\text { Letter no. } 9224 \text { - Paluka vs. the Ministry of } \\
\text { Agriculture }\end{array}$ & $\begin{array}{l}\text { Enforcement of } \\
\text { Decision }\end{array}$ \\
\hline $\begin{array}{l}2011,30 \\
\text { September }\end{array}$ & Bailiff Office in Tirana & $\begin{array}{l}\text { Letter no. } 10335 \text { - Paluka v s. the Ministry of } \\
\text { Agriculture }\end{array}$ & $\begin{array}{l}\text { Enforcement of } \\
\text { Decision }\end{array}$ \\
\hline 2011,03 & Bailiff Office in Tirana & Letter no. 09/118 - Trupja vs. Maritime Directorate & Enforcement of \\
\hline
\end{tabular}




\begin{tabular}{|c|c|c|c|}
\hline November & & & Decision \\
\hline $\begin{array}{l}2011,08 \\
\text { November }\end{array}$ & Treasury Branch of Tirana & $\begin{array}{l}\text { Letter no. } 3020 \text { - Paluka v s. the Ministry of } \\
\text { Agriculture }\end{array}$ & $\begin{array}{l}\text { Enforcement of } \\
\text { Decision }\end{array}$ \\
\hline $\begin{array}{l}2011,07 \\
\text { December }\end{array}$ & Bailiff Office in Tirana & $\begin{array}{l}\text { Letter no. } 13096 \text {-Paluka vs. the Ministry of } \\
\text { Agriculture }\end{array}$ & $\begin{array}{l}\text { Enforcement of } \\
\text { Decision }\end{array}$ \\
\hline 2012, 12 January & Bailiff Office in Durres & Decision no. 09/118- Trupja vs. Drejtoria Detare & $\begin{array}{l}\text { Enforcement of } \\
\text { Decision }\end{array}$ \\
\hline 2012,18 January & Treasury Branch of Tirana & $\begin{array}{l}\text { Letter no. 3440/2 - Paluka vs. the Ministry of } \\
\text { Agriculture }\end{array}$ & $\begin{array}{l}\text { Enforcement of } \\
\text { Decision }\end{array}$ \\
\hline 2012, 16 March & Bailiff Office in Tirana & $\begin{array}{l}\text { Letter no. } 2645 \text { - Paluka v s. the Ministry of } \\
\text { Agriculture }\end{array}$ & $\begin{array}{l}\text { Enforcement of } \\
\text { Decision }\end{array}$ \\
\hline 2012, 08 April & Bailiff Office in Tirana & Letter no. 3686 - Paluka vs. Ministry of Agriculture & $\begin{array}{l}\text { Enforcement of } \\
\text { Decision }\end{array}$ \\
\hline 2012, 23 May & CommissionerP.D & Decision no. 11 - S.C. vs. Harry Fultz School & TreatmentatWork \\
\hline 2012, 25 May & $\begin{array}{l}\text { College of the Supreme } \\
\text { Court }\end{array}$ & Decision no. 1189 - Sinani vs. UAMD & Work contract \\
\hline 2012, 01 June & DistrictCourt of Tirana & Decision no. 3331 - Kastoria vs. Academy of Arts & Work contract \\
\hline 2012, 19 July & Constitutional Court & Decision no. 42 - Paluka vs. Ministry of Agriculture & Work contract \\
\hline 2012, 30 July & Commissioner P.D & $\begin{array}{l}\text { Decision no. } 13 \text { - F.K. vs. Regional Directorate of } \\
\text { Health Fier }\end{array}$ & TreatmentatWork \\
\hline $\begin{array}{l}2012,08 \\
\text { November }\end{array}$ & Commissioner P.D & $\begin{array}{l}\text { Decision no. } 21 \text { - F.K. vs. Regional Directorate of } \\
\text { Health Fier }\end{array}$ & $\begin{array}{l}\text { Enforcement of } \\
\text { Decision }\end{array}$ \\
\hline $\begin{array}{l}\text { 2012, } 19 \\
\text { November }\end{array}$ & District Court of Shkodra & $\begin{array}{l}\text { Decision no. } 51 \text { - Semanaj vs. the Department of } \\
\text { Public Health of Malesia e Madhe }\end{array}$ & Work contract \\
\hline 2013, 20 February & Constitutional Court & Decision no. 4 - Trupja vs. Maritime Directorate & Work contract \\
\hline 2013, 04 June & DistrictCourt of Fier & $\begin{array}{l}\text { Decision no. } 1017 \text {-F.K. vs. RegionalDirectorate of } \\
\text { Health Fier }\end{array}$ & Salary / work position \\
\hline 2013, 18 October & Commissioner P.D & Decision no. 103 - Kosturi v s. Academy of Arts & TreatmentatWork \\
\hline \multicolumn{4}{|c|}{2014 (characterized by increasedlevel of GEW) } \\
\hline 2014, 01 June & Appeal Court of Tirana & Decision no. 3331 - Kastoria vs. Arts Academy & Work contract \\
\hline 2014,05 February & Constitutional Court & Decision no. 5 - Deputies vs. Executive \& legislafve & Work contract \\
\hline 2014,20 February & Appeal Court of Vlora & $\begin{array}{l}\text { Decision no. } 280-F . K \text {. vs. Regional Directorate of } \\
\text { Health Fier }\end{array}$ & Salary / work position \\
\hline 2014,30 October & Constitutional Court & Decision no. 2 - Sinani vs. UAMD & Work contract \\
\hline
\end{tabular}

The second reality tells about the decisions made by the Albanian judiciary, keeping account of the standards of international instruments and cases tried by international court. Even before 2006, the Albanian judiciary has addressed the issue of equity before the law in a number of practices and decisions of the Constitutional Court of Albania. ${ }^{1}$ But during the period of 2006-2014, in the decisions of the Albanian judicial, are noticed a number of specific references to the

1 Some decisions include: 1) Decision No. 11, 8/27/1993, 2) Decision no. 71, 2/12/1998, 3) Decision No. 16, 4/17/2000,4) Decis ion no. $171,30.7 .2002$, and 5) Decision no. 34, 12.20.2005. For more details about these decisions, see "Summary Decisions" pp. 1992-1997. 91; pp. 1997-1999. 206; 2000 p. 20; 2002 p. 184; and 2005 p. 289. 
European Convention of Human Rights (ECHR), the European Court of Human Rights (ECHR), or the EU Directives. The most frequent references to the ECHR are those for Article 6 of the ECHR that stipulate the right to a fair hearing, ${ }^{1}$ Article 13 of the ECHR that states the right to equal treatment in front of the law, ${ }^{2}$ Article 14 of the ECHR that defines the circumstances that constitute discrimination, ${ }^{3}$ or Article 41 of EDHR that defines the right to a fair trial. ${ }^{4}$ Also, in the decisions of the Albanian Constitutional Court are observed references to the jurisprudence of the ECHR, ${ }^{5}$ as well as to the EU Directives for equal treatment. ${ }^{6}$

The third reality that was observed in cases of discrimination and GEW reviewed by Albanian courts reflects the following five features: 1) trial of the same case of discrimination on two or more levels of the Albanian judiciary, 2) accordance among courts of different levels on the decisions taken from them, 3) non-enforcement of the decisions of courts, 4) nonimplementation of decisions and recommendations of the Commissioner for Protection from Discrimination, and 5) resolution of the conflict only by the decision of the Constitutional Court. Among the cases that reflect these features, four are the most typical ones: 1) The case of Semanaj vs. the Department of Public Health of Malesia e Madhe, 2) The case of F.K vs. Regional Directorate of Health Fier, 3) The case of Paluka vs. the Ministry of Agriculture, and 4) the case of the Trupja vs. the Marine Department of the Port of Durres.

In the case of Semanaj vs. the Department of Public Health of Malesia e Madhe (DPHMM) gender discrimination consists in the removal of Mrs. Semanaj on maternity leave, shortening of job position and termination of the contract and disrespect of the procedures and notification deadlines. The conflict was judged on two levels: the Court of First Instance of Shkodra and the Court of Appeal of Shkodra. ${ }^{7}$ The decisions of the two courts were in favor of Mrs. Semanaj declaring the termination of the employment contract to be invalid, and asking the DPHMM to return her to her former place of work, and asking salary compensation for Mrs.Semanaj for all the time since the termination of the contract. DPHMM did not enforce the decisions of the courts and in order to ensure the implementation of the decisions it was necessary the issuance of an order for the Bailiff Office of Shkodra. This institution took the necessary actions to urge the PHDMM to implement court decisions. ${ }^{8}$

In the case of F.K. vs. the Regional Directorate of Health Fier (RDHF), it was about a direct gender discrimination and victimization. Mrs. F.K. initially was lowered in her position from "head of the sector" to "nurse", and was transferred from her previous place of work in another city, her salary was reduced by approximately $50 \%$, and then she was completely dismissed from work. In her place was appointed a male person without the relevant education and experience for that position. The conflict was handled by the Commissioner for Protection from Discrimination, ${ }^{9}$ and the court of two levels:

\footnotetext{
${ }^{1}$ This article refers to the Constitutional Court decided in three decisions:1) Decisionno. 42, 19.07. 2012 (Paluka vs. Ministry of Agriculture), 2) Decision no. 4, 20. 02. 2013 (Trupja vs. Port of Durres), and 3) Decision no. 2, 20. 10. 2014 (Sinanaj vs. UAMD). ${ }^{2}$ Reference to this article were made in court decisions three different lev els: Shkoder Court, Decision no. 1057, 04/22. 2009 (Semanaj v.s DPHMM); The Court of Appeal Vlora, Decision 280, 20.02.2014 (F.K vs. RDHF), and the Constitutional Court, Decision no. 2, 20. 10. 2014 (Sinanaj vs. UAMD).

${ }^{3}$ Reference to this article is observ ed in a great number of decisions and in all the judiciary levels, constitutional, court of appeal, court of first instance. The constitutional court refers in Decision 33, 12, 09, 2007 (Joint College of the Supreme Court (JCSC) vs. Executive \& Legislative); Vlora Court of Appeal refers to Decision 280, 20. 02.2014 (F.K vs. RDHF); Reference to this article observed in judicial decisions in the courts of firstinstance: Shkoder Court, Decision no. 1057, 22. 04. 2009 (Semanaj vs. DPHMM), and the Court of Fier, Decision no. 62, 04. 06. 2013 (F.K vs. RDHF). Reference to this article observed in tw o decisions of the Commissioner for Protection against Discrimination (CPD): 1) Decision 11, 23. 05. 2012 (S.C vs. Harry Fultz School), and 2) Decision no. 103, 18. 10. 2013 (Kastoria vs. Arts Academy).

${ }^{4}$ This article referred to the Constitutional Court Decision no. 42, 19. 07. 2012 (Paluka vs. MBMUK).

${ }^{5}$ Constitutional CourtDecision 33, 12.09.2007 (Joint College of the Supreme Court [JCSC] vs. the Executive \& Legislative).

${ }^{6}$ Decision no. 33, 12.09.2007 (Joint College of the Supreme Court [JCSC] vs. the Executive \& Legislative), Albania's Constitutional Court refers specifically to the EU Directive $78 / 2000$ "On the establishment of a regulatory framework for equal treatment at w ork relations."

${ }^{7}$ Decision no.1057, 22. 04. 2009, the Court of Shkodra, Semanaj vs. Department of Public Health of the Great Highland; Decision 5, 11. 01. 2010, the Appellate Court of Shkodra, Semanaj vs. Department of Public Health of the Great Highland.

${ }^{8}$ Decision no.51, 19. 11. 2012, the District Court of Shkodra.

9 Decision no. 13, 30. 07. 2012, the Commissioner for Protection from Discrimination, FK vs. Regional Directorate of Health Fier; Decision no. 21, 08. 11. 2012, the Commissioner for Protection from Discrimination, FK vs. Regional Directorate of Health Fier.
} 
District Court of Fier, and the Court of Appeal of Vlora. ${ }^{1}$ Both the Commissioner and the courts issued decisions in fav or of F.K. They asked RDHF to return Mrs. F.K to work, back to her previous position as "Head of the Sector" and indemnify Mrs. F.K. for the period she was left without work. The Commissioner requested report within 30 days after the decision of the measures taken by RDHF. The latter did not implement any decision and for this reason RDHF was fined by the Commissioner with 60,000 new ALL.2

The case of Paluka vs. the Ministry of Agriculture, Nutrition and Consumer Protection (Ministry of Agriculture), was about gender discrimination and termination of labor relations with Mrs. Paluka without respecting the legal process. The conflict was judged by the Civil Service Commission ${ }^{3}$ and the Court in three levels: the Court of Appeals of Tirana, ${ }^{4}$ the Civil College of the Supreme Court ${ }^{5}$ and the Constitutional Court of Albania. ${ }^{6}$ Both the Civil Service Commission and the courts favored Mrs. Paluka. The Civil Service Commission changed the disciplinary measures given by the Ministry of Agriculture of "dismissal from work" to "written warning," and asked the Ministry of Agriculture to return Mrs. Paluka to her previous position and to compensate for the time left without work. Both the Court of Appeals in Tirana and the Civil College of the Supreme Court, made the same decision, as also did the Civil Service Commission, favoring Mrs. Paluka. The Ministry of Agriculture refused to enforce the decisions of the Commission and the Court. It opposed and prevented the execution of the orders of the Bailiff Office and those of the Treasury Branch of Tirana. The Bailiff Office of Tirana, during the period of 2011-2012, sent to the Ministry of Agriculture nine letters to give notice and also asked it to voluntary enforce the decision, ${ }^{7}$ and also requested forced execution, ${ }^{8}$ enforcement of the executive tite, ${ }^{9}$ and measures were taken for the execution of the decision. ${ }^{10}$ The Bailiff Office of Tirana also sent to the Treasury Branch of Tirana two letters, one for conservative seizure, ${ }^{11}$ and another one for the measures taken by the Treasury. ${ }^{12}$ The Treasury Branch Tirana, in both letters, informed Bailiff Office of Tirana to block the budget funds of the Ministry of Agriculture. ${ }^{13}$ Despite the court's decision and the actions of the Bailiff Office of Tirana and the Treasury Branch of Tirana, the Ministry of Agriculture refused to implement the decisions of the courts and to indemnify Mrs. Paluka according to the amount fixed by the courts. In an order addressed to the Treasury Branch of Tirana, the Ministry of Agriculture started conducting a monthly payment for the compensation of Mrs. Paluka, but it was several times lower than the amount ordered by the court. ${ }^{14 / 100}$ The Ministry of Agriculture is obligate to fully implement the decisions of the courts only after the decision of the Constitutional Court of

\footnotetext{
${ }^{1}$ Decision no.1017, 04. 06. 2013 Fier District Court, FK vs. Regional Directorate of Health Fier; Decision no. 280, 20. 02. 2014, the Court of Appeal Vlora, F.K. vs. Regional Directorate of Health Fier.

2 Decision no. 21, 08. 11. 2012, the Commissioner for Protection from Discrimination, F.K vs. Regional Directorate of Health Fier.

${ }^{3}$ Decision no. 127, 25. 11. 2010, the Civil Service Commission, Paluka vs. Ministry of Agriculture, Food and Consumer Protection (Ministry of Agriculture).

${ }^{4}$ Decision no. 23, 01. 03. 2011, the Court of Appeals of Tirana, Paluka vs. Ministry of Agriculture, Food and Consumer Protection (Ministry of Agriculture); Decision No.28, 24.03. 2011, the Court of Appeals of Tirana, Paluka vs. Ministry of Agriculture, Food and Consumer Protection (Ministry of Agriculture).

${ }^{5}$ Decision no. 986, 23. 06. 2011, the Civil Division of the High Court, Paluka vs. Ministry of Agriculture, Foodand Consumer Protection (Ministry of Agriculture).

${ }^{6}$ Decision no. 42, 19. 07. 2012, the Constitutional Court of Albania, Paluka vs. Ministry of Agriculture, Food and ConsumerProtection (Ministry of Agriculture).

${ }^{7}$ Bailiff Office of Tirana, Requested the MAFCP for voluntary executions, Letter no. 4386, 11. 04. 2011.

${ }^{8}$ Bailiff Office of Tirana, Request for the MAFCP for forced executions, letter no. 6552, 13.06. 2011, letter no. 8314, 28. 07. 2011, Letter no. 2645, 16. 03. 2012.

${ }^{9}$ Bailiff Office of Tirana, Requested the MAFCP for the ex ecution of the ex ecutive title, Letter no. 8314, 28. 07. 2011, Letter no. 9224, 08. 09. 2011, Letter no. 10335, 30. 09. 2011.

${ }^{10}$ Bailiff Office of Tirana, informing MAFCP to take measures to execute the ex ecutive title, Letter no. 2645, 16. 03. 2012, and Memo no. 3686, 08. 04. 2012.

${ }^{11}$ Bailiff Office of Tirana, Order for the Treasury Branch of Tirana for conservative seizure to the Ministry of Agriculture, Letter no. 13 096, 07. 12. 2011.

${ }^{12}$ Bailiff Office of Tirana, Tirana Treasury Branch, Request for information about the measures taken by the Treasury for execution, Letter no. 3686, 08. 04. 2012.

${ }^{13}$ Treasury Branch of Tirana, Bailiff Office of Tirana blocking budgetary funds of the Ministry of Agriculture, Letter no. 3020, 08. 11. 2011, Letter no. 3440/2, 18. 01. 2012.

${ }_{14}$ Ministry of Agriculture, Letter no. 125, 06. 03. 2012, the Treasury Branch Tirana, For payment of 10,000 new ALL per month to Mrs.

Paluka.
} 
Albania. 1/101 The Constitutional Court, as well as the courts of lower levels, ruled in favor of Ms Paluka. Besides the obligation of the Ministry of Agriculture to implement the decisions of other courts, the Constitutional Court in its decision reminds the Ministry of Agriculture of the fact that state institutions are obliged to enforce the final judicial decisions and that this obligation derives directly from the Constitution. The state institutions cannot put into question the fairness of the final judicial decisions and they have to implement them. Also, the execution of the decisions cannot be extended indefinitely.

The issue of Trupja vs. Maritime Directorate in the Port of Durres, is about directly discrimination, contract termination and dismissal of Mrs. Trupja, and disrespect for both the legal process and the decisions of the courts. Also this conflict was judged by three degrees of judiciary: Durres District Court, ${ }^{2}$ Court of Appeal of Durres, ${ }^{3}$ Albania's Constitutional courts. ${ }^{4}$ As the Court of First Instance, the Court of Appeal also took a decision in favor of Mrs. Trupja. They have asked the Maritime Administration to return Mrs. Trupja to work and be compensated by paying for the entire period of leave without work. During the period 2008-2012, the Maritime Directorate refused to implement the court order. It also denied its responsibilities and did not respond to six requests of the Bailiff Office of Durres for voluntary execution, ${ }^{5}$ for the legal obligations, ${ }^{6}$ for mandatory execution, ${ }^{7}$ fining for negligence to act, ${ }^{8}$ criminal charges, ${ }^{9}$ and seizure. ${ }^{10}$ The Marine Department implemented the court orders only after the decision of the Constitutional Court of Albania. The latter, in its decision, reminded the Maritime Directorate that the execution of a decision constitutes an essential element of the rule of law and the very notion of a fair trial. Every state body is obliged to take the appropriate measures for their implementation. Also, execution within a reasonable time of a final decision is part of the right to a fair hearing and only after the execution of the decision may the individual consider his right fully respected. Although delays in execution of a judgment may exist, delays cannot be to such an extent as to undermine the essence of the law. No citizen should wait indefinitely for the realization of a right recognized by a court decision. The execution of the decision represents a stage of the same process, thus the non-execution of a final decision by the Maritime Directorate was found inexcusable. Public or private authorities have an obligation for the implementation of the final court decisions. In this sense, the refusal of the Maritime Directorate to implement the order for execution of the court decisions for a period of 4 years and 10 months is totally unacceptable.

\section{Some Conclusions}

The GEW in Albania has been characterized not only by an increase but is whirling between growth and decline. Even in the late 2014 the GEW level results lower than in 2006. The question that emerges from this analysis then is: If the increase decrease dynamics of the trends and levels in Albania cannot be explained with the role of the legal factors, more precisely, only with the role of the legislative instruments, the executive, or the Albanian judiciary, what can explain the increasedecrease dynamics of the GEW in Albania?

This paper concludes that although the Albanian legal factors can be considered a positive force for the GEW in Albania, whether in terms of the role, whether in terms of the character of their influence, again, they cannot fully ex plain what happens to GEW in Albania. The explanation may be sought in other non-legal factors. The analysis of the role of the courts in this paper shows that there is reason to believe that explanation in the GEW in Albania cannot be complete without including in the explanatory model the role of cultural and social factors. In discrimination cases analyzed above, we saw that almost all courts of all levels had made decisions in fav or of Gender Equity. Yet decisions were not implemented. The subjects that did not enforce the decisions were not only private legal entities but also public legal entities and institutions such as the Ministry of Agriculture.

\footnotetext{
${ }^{1}$ Decision no. 42, 19. 07. 2012, the Constitutional Court of Albania, Paluka vs. Ministry of Agriculture, Food and ConsumerProtection (Ministry of Agriculture).

2 Decision no. 2918, 12. 12. 2006, the District Court of Durres, Mrs.Trupja vs. Durres Port Maritime Directorate (DPMD); Execution Order no. 36, 21. 01. 2008, the District Court of Durres, Mrs.Trupja vs. Durres Port Maritime Directorate (DPMD).

${ }^{3}$ Decision no. 540, 03. 12. 2007, the Court of Appeal of Durres, Trupja vs. Durres Port Maritime Directorate (DPMD).

${ }^{4}$ Decision no. 4, 20. 02. 2013, the Constitutional Court of Albania, Trupja vs. Durres Port Maritime Directorate (DPMD).

${ }^{5}$ Bailiff Office of Durres, Marine Department, Request for v oluntary execution, Letter no. 864, 21.04. 2008.

${ }^{6}$ Bailiff Office of Durres, Marine Department, Request for a term of 10 day s for information about the undertaking of the rights and duties of the former Director of the Port of Durres, Letter no. 184/10 27. 12. 2010.

${ }^{7}$ Bailiff Office of Durres, Order Maritime Directorate for compulsory execution, Letter no. 09/118, 13. 06. 2011.

${ }^{8}$ Bailiff Office of Durres, 50,000 new ALL fine to the Maritime Directorate for negligence to act, Decisionno. 09/118, 25. 08. 2011.

${ }^{9}$ Bailiff Office of Durres, Criminal charges against the General Director of the Directorate Marine, Letter no.09/118, 03.11. 2011.

${ }^{10}$ Bailiff Office of Durres, seizure order for operating ex penses to the Maritime Directorate for the amount of 936,849 new ALL Decision no. $09 / 118,12.01 .2012$.
} 
This results in the conclusion that GEW in Albania, more than a matter of instruments, laws of the legislative, acts of the executive, or judicial decisions, it remains at a considerable degree a matter of culture and behavior of the individual on a personal level, of the social group, or that of the state institutions. The lack of a full understanding and awareness of the GEW from the individuals and social groups or institutions and therefore everyday life conduct and relations through the aware or unaware negligence of the principle of gender equity, leads to a continuing presence of the cases of gender discrimination regardless of the public or private area, outside or inside the institutions. Cultural problems with understanding, awareness, customs and practices, can perhaps best explain why GEW in Albania whirls around an increase and decrease of its level. 